\title{
MEMBERS OF THE COUNCIL
}

\section{OFFICERS}

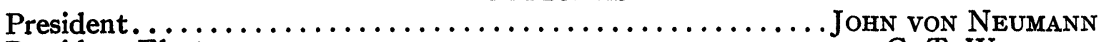

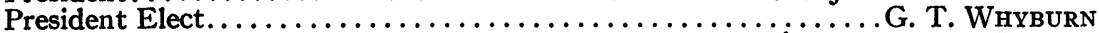

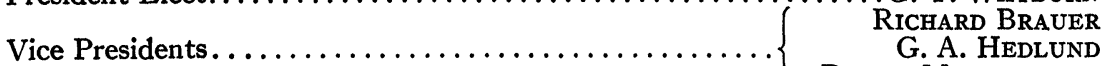

DEANe MONTGOMERY

Secretary.$\ldots \ldots \ldots \ldots \ldots \ldots \ldots \ldots \ldots \ldots \ldots \ldots \ldots \ldots \ldots \ldots \ldots \ldots \ldots \ldots \ldots$, G. BEGLE

Associate Secretaries ........................ $\quad \begin{aligned} & \text { L. W. CoHEN } \\ & \text { J. W. GreEn* }\end{aligned}$

W. M. WHYBURN

J. W. T. YOUNGS

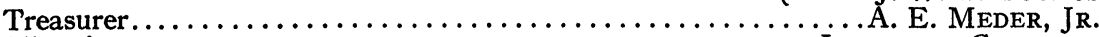

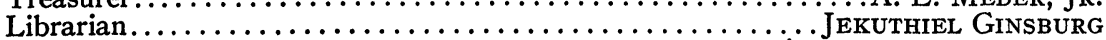

Bulletin Editorial Committee................. $\left\{\begin{array}{l}\text { W. T. MARTIN } \\ \text {. }\end{array}\right.$

G. A. Hedlund
G. Price

Proceedings Editorial Committee.................

A. C. SCHAEFFER

L. V. AHLFORS

Transactions Editorial Committee................. $\left\{\begin{array}{r}\text { L. V. AHLFoRS } \\ \text { J. DooB } \\ \text { SAUNDERs MACLANE }\end{array}\right.$

G. T. WHYBURN

Coll A. AlberT

EINAR HILLE

R. L. WILDER

Mathematical Reviews Editorial Committee........... $\begin{array}{r}\text { WILLIAM FELLER } \\ \text { EINAR HILLE }\end{array}$

HASSLER WHITNEY

W. T. MARTIN

R. J. WALKER LEO ZIPPIN

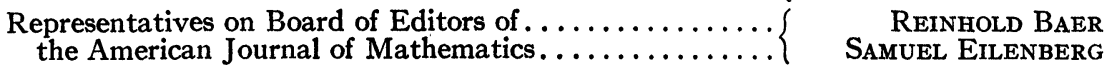
the American Journal of Mathematics.

SAMUEL EILENBERG

Former President

T. H. HILDEBRANDT

Former SECretary

J. R. KLINE

Members AT LARGe

To serve until

December, 1952

WARREN AMBrose

P. R. Halmos

MARK KAC

S. B. MEYeRS

D. C. SPENCER

M. H. HeINS $\dagger$

B. P. GILL

T. H. HILDEBRANDT JoHN voN NEUMANN, ex officio

\author{
To serve until \\ December, 1953 \\ D. H. BLACKWELL \\ H. F. BOHNENBLUST \\ H. S. M. Coxeter \\ IRVING KAPLANSKY \\ W. T. REID
}

To serve until

December, 1954

L. V. AHLFORS

C. B. AlLENDOERFER

R. H. BING

E. R. LORCH

J. C. Охтову

\section{BOARD OF TRUSTEES}

\author{
EINAR HiLle \\ J. R. KLINE \\ P. A. SMITH
}

A. E. MEDER, JR., ex officio

\section{EXECUTIVE COMMITTEE OF THE COUNCIL}

E. G. BEGLE

WiLliaM Feller

G. A. HEDLUND
JOHN VON NEUMANN

G. T. WHYBURN

R. L. WILDER

* For the academic year 1951-52, Professors Green and Jacobson were on leave of absence. Their places on the Council were filled by Professors W. T. Puckett and G. P. Hochschild respectively. t Professor Heins was elected a member-at-large of the Council for the period 1949-51. In January 1951, he was elected to the Executive Committee of the Council. According to Article VII, Section 4, of the by-laws, he remained on the Council through 1952. 